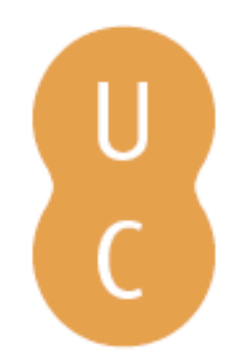

\title{
pombalina
}

\section{Forensic y-str study in y-chromosome abnormalities}

Autor(es): $\quad$ Silva, J.; Ribeiro, T.; Gonçalves, J.; Geada, H. Publicado por: Imprensa da Universidade de Coimbra; International Academy of Legal

URL

persistente: URI:http://hdl.handle.net/10316.2/31751

DOI: $\quad$ DOI:http://dx.doi.org/10.14195/978-989-26-0173-1_15

Accessed : $\quad$ 26-Apr-2023 13:16:03

A navegação consulta e descarregamento dos títulos inseridos nas Bibliotecas Digitais UC Digitalis, UC Pombalina e UC Impactum, pressupõem a aceitação plena e sem reservas dos Termos e Condições de Uso destas Bibliotecas Digitais, disponíveis em https://digitalis.uc.pt/pt-pt/termos.

Conforme exposto nos referidos Termos e Condições de Uso, o descarregamento de títulos de acesso restrito requer uma licença válida de autorização devendo o utilizador aceder ao(s) documento(s) a partir de um endereço de IP da instituição detentora da supramencionada licença.

Ao utilizador é apenas permitido o descarregamento para uso pessoal, pelo que o emprego do(s) título(s) descarregado(s) para outro fim, designadamente comercial, carece de autorização do respetivo autor ou editor da obra.

Na medida em que todas as obras da UC Digitalis se encontram protegidas pelo Código do Direito de Autor e Direitos Conexos e demais legislação aplicável, toda a cópia, parcial ou total, deste documento, nos casos em que é legalmente admitida, deverá conter ou fazer-se acompanhar por este aviso.

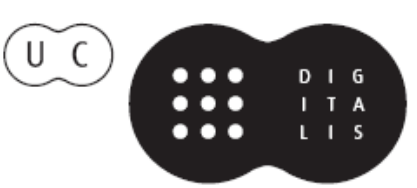




\section{Duarte Nuno Vieira Anthony Busuttil \\ Denis Cusack • Philip Beth}
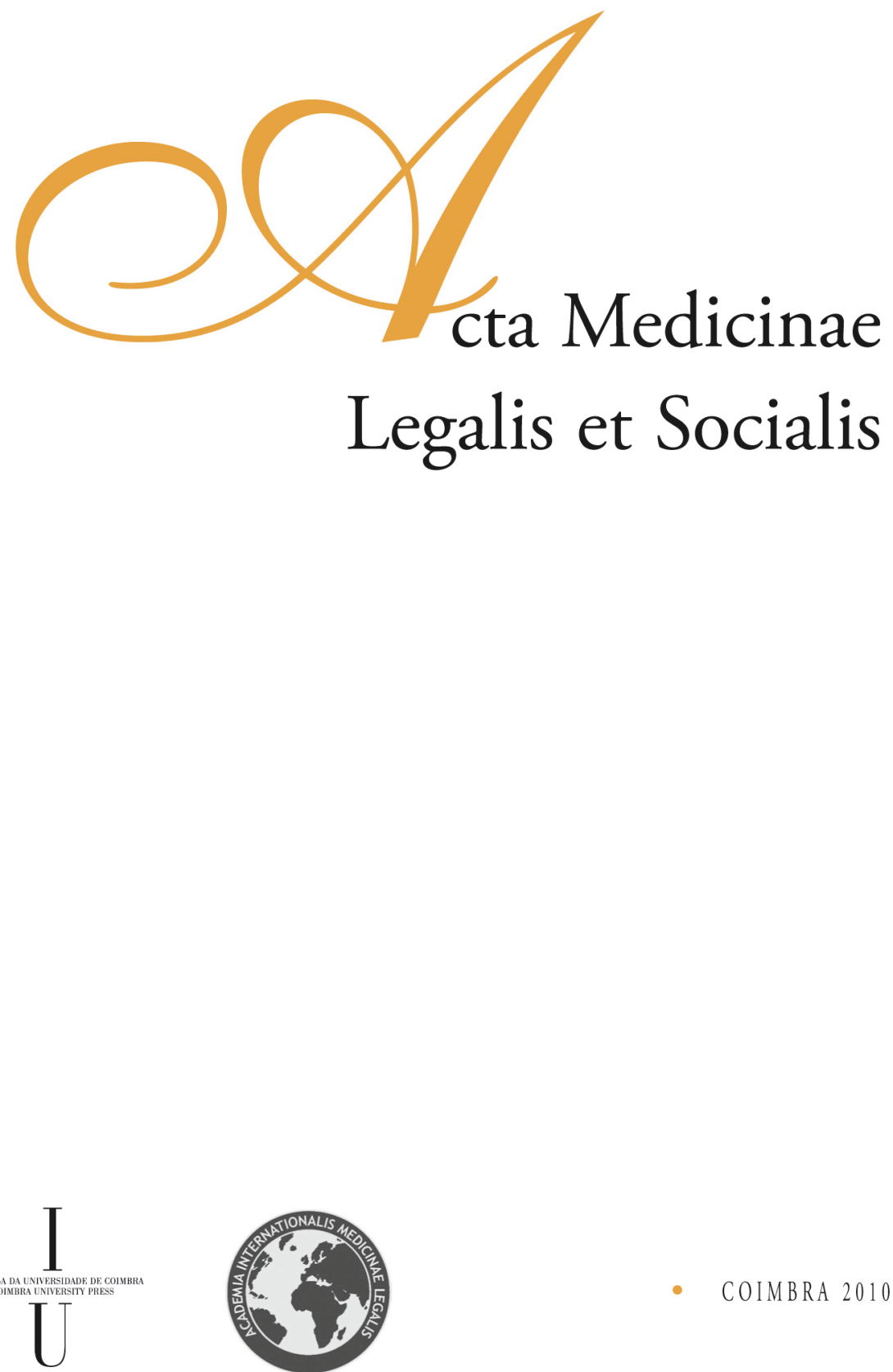
J. Silva ${ }^{1,3}$, T. Ribeiro ${ }^{2}$, J. Gonçalves ${ }^{3}$, H. Geada ${ }^{1,2}$

${ }^{1}$ Faculty of Medicine, University of Lisbon, Portugal

${ }^{2}$ Forensic Genetics and Biology Department, South Branch of the National Institute of Legal Medicine, Lisbon, Portugal

${ }^{3}$ Genetics Department, Molecular Genetics Centre, National Institute of Health Dr Ricardo Jorge, Lisbon, Portugal

\title{
FORENSIC Y-STR STUDY IN Y-CHROMOSOME ABNORMALITIES
}

\begin{abstract}
Y-chromosome infertility is usually caused by deletions of genetic material in Azoospermia Factor (AZF) regions, localized in three nonoverlapping Yq regions - AZFa, $\mathrm{AZFb}$ and AZFc. However, some of the Y-STRs routinely studied in Forensic Genetics with multiplex kits are localized in these three regions giving rise to microdeletions observed in some loci. Rare alleles were also encountered in these samples with Y-chromosome structural changes. A complete Y-STR profile in a sample from a female individual was detected which may raise ethical implications. The aim of this work is to assess the validity in the use of Y-STR multiplex systems in structurally abnormal Y-chromosomes, which may occur in forensic casework analysis.
\end{abstract}

Keywords: AZF regions; Y-STRs; microdeletions.

\section{Introduction}

Y-chromosome infertility is usually caused by deletions of genetic material in AZF region, localized in three no overlapping Yq regions - AZFa, AZFb and AZFc (1-3). Microdeletions are rare in AZFa region, concerning 1-2\% of total deletions in AZF region. The most frequent microdeletions are observed in AZFc region where we encountered $80 \%$ of total AZF region deletions $(4,5)$. However, some of the Y-STRs routinely studied in Forensic Genetics are placed in these three regions (6). The aim of this work is to assess the validity in the use of Y-STRs in structurally abnormal Y-chromosomes, which may occur in forensic casework.

\section{Material and Methods}

Y-STRs were studied with AmpFISTR® Yfiler® in 46 samples previously screened for AZF region deletions and with informed consent. DNA samples from these individuals were provided as blind samples, not being known how many individuals had AZF microdeletions. Samples of 50 individuals also with informed consent and with clinical indication of male infertility but with no Y chromosome deletions (control samples) were also studied. Control samples were also previously characterized at the molecular level, using Y chromosome specific STS (Single Tagged Site) concerning these 
three AZF regions: AZFa - DFFRY3', DBY; AZFb - sY1227, sY1224, sY134, sY119, sY134, RBMY1, sY143; AZFc - sY1192, sY254, RRM3, sY1291, sY283, sY1201.

DNA extraction was done by "Salting in salting out" method with Wizard Genomic DNA kit (Promega) and, more recently, automatic extraction with MagNa Pure LC DNA Isolation Kit (Roche). AmpFISTR ${ }^{\circledR}$ Yfiler ${ }^{\circledR}$ PCR Amplification kit (Applied Biosystem) was used for studying the following 16 loci-DYS456, DYS389I, DYS390, DYS389II, DYS458, DYS19, DYS385, DYS393, DYS391, DYS439, DYS635, DYS392, GATAH4, DYS437, DYS438 and DYS448. Capillary electrophoresis was performed in a 3130 Genetic Analyser with $36 \mathrm{~cm}$ capillaries with POPTM4 (Applied Biosystems), using specific software GeneMapper IDv3.2.

\section{Results}

Forty-six samples were previously screened for AZF region deletions by using Y chromosome specific STS (Single Tagged Site) (Table1). DNA samples from these individuals were provided as blind samples, not being known how many individuals had AZF microdeletions. Four cases with no amplification of DYS385, DYS392 and DYS488 loci were detected (Fig.1 and Table 2), suggesting microdeletions in the AZFb region (Table2). From the Y-chromosome map positions, DYS385, 392 and 448 are located in the AZFb region, while DYS434, 437, 435, 439, 389I/II, 388, 438 and 436 are located in the AZFa region. DYS 391, 393 and 19 are not assigned to these regions. Using Yfiler multiplex system, rare alleles were observed in DYS 458 (allele17.2), DYS385 (allele12.1) and GATAH4 (allele14.1) loci. Concerning control samples, there was no suggestion of microdeletions although some rare alleles were also present in DYS458 (alleles16.2, 17.2 and 18.2) and DYS635 (allele17). A complete Y-STR profile was detected in a sample belonging to a female individual, although with a 46, XY karyotype (Fig.2).

\section{Discussion and Conclusions}

The existence of Y-chromosome microdeletions is a phenomenon with which Forensic Geneticists may have to deal. In case of such an occurrence, is of great importance to know how to interpret the nature of these results, given the structural changes of the Y-chromosome. In all control samples, a full Y-STR profile was obtained, confirming molecular information previously obtained with STS analysis. Four cases of non amplification of DYS385, DYS392 and DYS488 loci were detected, suggesting microdeletions in the AZFb region which was confirmed by single tagged site studies. Rare alleles not previously detected in Portuguese population studies were also encountered in several Y-STR loci.

A complete Y-STR profile was detected in a sample belonging to a female individual, although with a 46, XY karyotype. This is a well known clinical situation, even though of rare occurrence. Complete Y-STR profiles in samples from female gender individuals may raise ethical implications and, above all, increase the difficulty in the interpretation of physical evidence in criminal investigation casework. 


\section{References}

1. M. NAMIKI, Aspects of male infertility, World Journal of Surgery, 24, 1176-1179, 2000.

2. P.H. VOGT, Genomic heterogeneity and instability of the AZF locus on the human Y chromosome, Molecular and Cellular Endocrinology, 224, 1-9, 2004.

3. C. KRAUSZ, Y chromosome and male infertility, Andrologia, 37, 219-223, 2005.

4. A. FERLIN, E. MORO, A. ROSSI, B. DALlAPICCOLA, C. FORESTA, The human Y chromosome's azoospermia factor $\mathrm{b}$ (AZFb) region: sequence, structure, and deletion analysis in infertile men, J.Med.Genet., 40,18-24, 2003.

5. T. KURUDA-KAWAGUCHI, H. SKALETSKY, L.BROWN et al., The AZFc region of the $Y$ chromosome features massive palindromes and uniform recurrent deletions in infertile men, Nature Genetics 29, 279-286, 2001.

6. M.A. JOBLING, C.TYLER-SMITH, The Human Y chromosome: an evolutionary marker comes of age, Nature Genetics 4, 598-612, 2003.

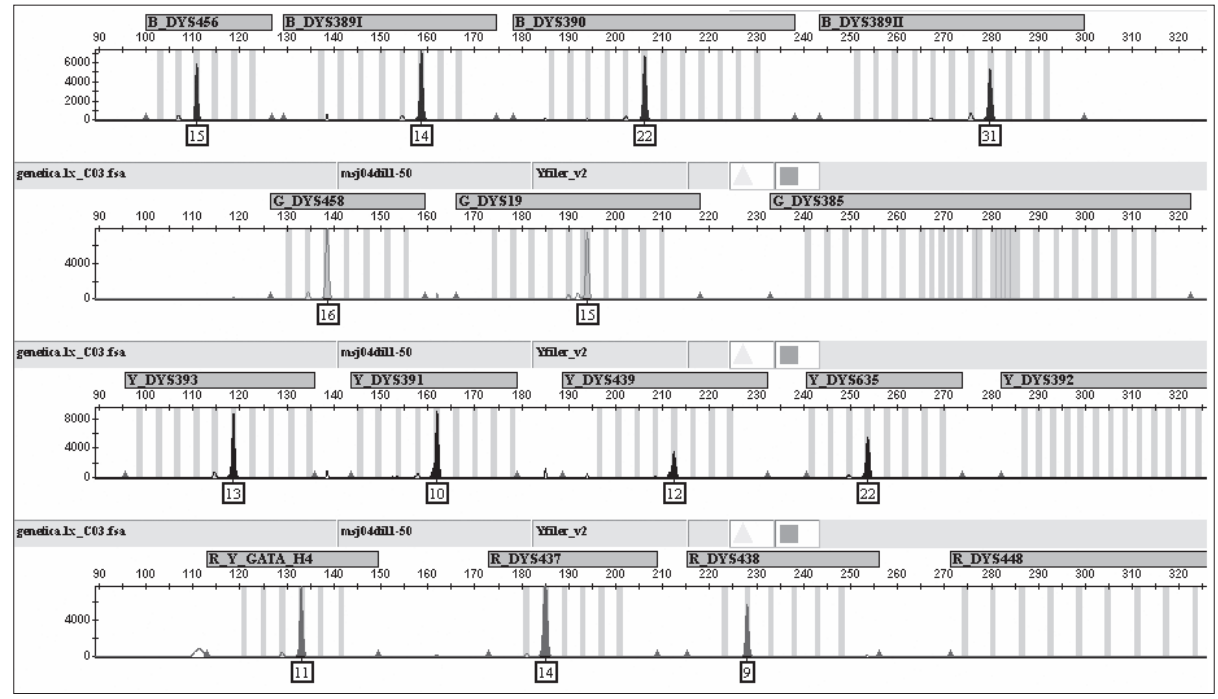

Figure 1 - Y-STR profile performed with Yfiler showing no amplification in DYS385, DYS392 and DYS448 loci 


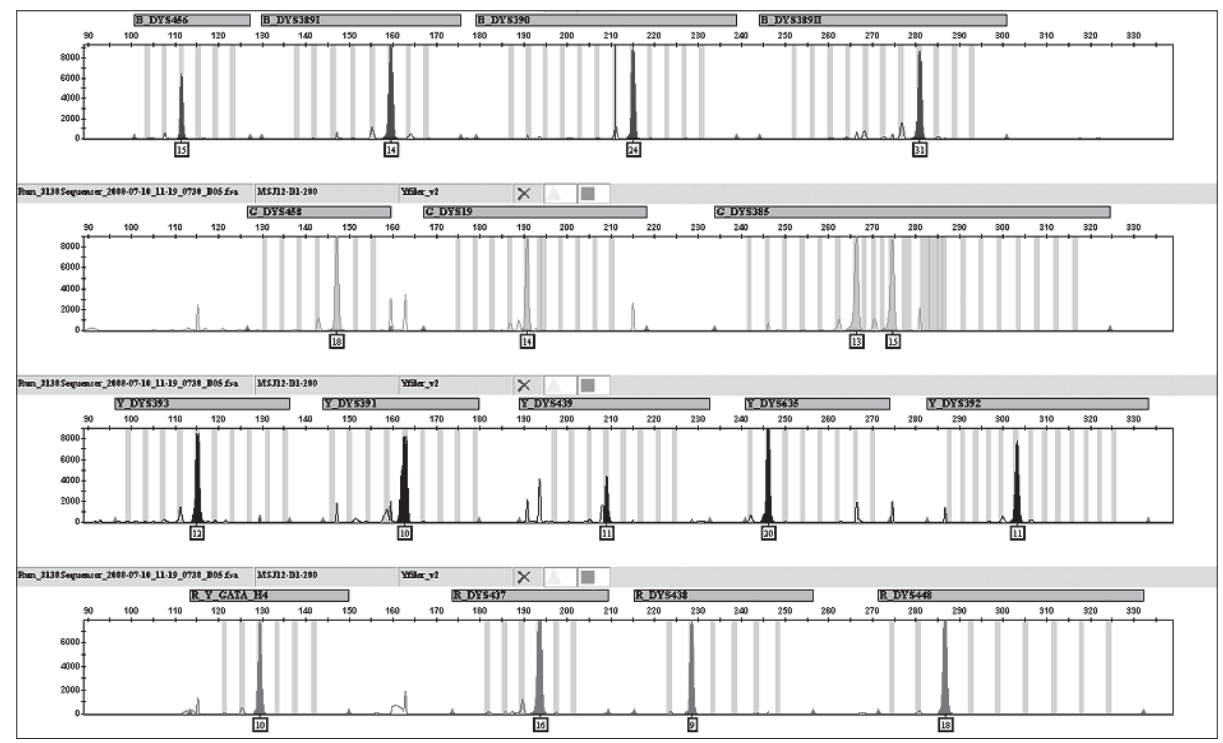

Figure 2 - A complete Y-STR profile was detected in a sample belonging to a female individual, although with a 46, XY karyotype.

\begin{tabular}{|c||c|c||c|c|c|}
\hline $\begin{array}{c}\text { AZF } \\
\text { Region }\end{array}$ & $\underline{\text { STS's }}$ & $\underline{\text { Sample1 }}$ & $\underline{\text { Sample2 }}$ & $\underline{\text { Sample3 }}$ & $\underline{\text { Sample4 }}$ \\
\hline \multirow{3}{*}{ AZFa } & $D F F R Y-3^{\prime}$ & Present & Present & Present & Present \\
\cline { 2 - 6 } & $D B Y$ & Present & Present & Present & Present \\
\hline \multirow{5}{*}{ AZFb } & sY1227 & - & - & - & - \\
\cline { 2 - 6 } & sY1224 & - & - & - & - \\
\cline { 2 - 6 } & sY119 & - & - & - & - \\
\cline { 2 - 6 } & sY134 & - & - & - & - \\
\cline { 2 - 6 } & RBMY1 & - & - & - & - \\
\cline { 2 - 6 } & sY143 & - & - & - & - \\
\hline \multirow{5}{*}{ AZFc } & sY1192 & Present & - & - & - \\
\cline { 2 - 6 } & sY254 & Present & - & - & - \\
\cline { 2 - 6 } & RRM3 & Present & - & - & - \\
\cline { 2 - 6 } & sY1291 & Present & - & - & - \\
\cline { 2 - 6 } & sY283 & Present & - & Present & - \\
\cline { 2 - 6 } & sY1201 & Present & - & Present & - \\
\hline
\end{tabular}

Table 1 - Four examples of microdeletion results obtained with single tagged sites concerning AZF regions.

\begin{tabular}{|c|c|c|c|c|c|c|c|c|c|c|c|c|c|c|c|c|c|}
\hline Amostr: & Sexol & YS19 & YS389I & DYS389II & DYS456 I & DYS390 I & DYS458 I & DYS385 & DYS3931 & DYS391 I & DYS439 I & DYS635I & DYS392 C & GATAH4 & DYS437 & DYS438 I & DYS448 \\
\hline & $\mathrm{M}$ & 14 & 13 & 29 & \begin{tabular}{|l|}
15 \\
\end{tabular} & \begin{tabular}{l|}
23 \\
\end{tabular} & \begin{tabular}{|l|}
18 \\
\end{tabular} & $11-14$ & 13 & 11 & \begin{tabular}{|l|}
12 \\
\end{tabular} & 23 & \begin{tabular}{l|}
13 \\
\end{tabular} & \begin{tabular}{|l|}
12 \\
\end{tabular} & \begin{tabular}{l|}
15 \\
\end{tabular} & 12 & 19 \\
\hline & $\mathrm{M}$ & 14 & 13 & 29 & 15 & 23 & 17.2 & $14-17$ & 12 & 10 & 12 & 20 & 11 & 11 & 14 & 10 & 20 \\
\hline 1 & $\mathrm{M}$ & 14 & 13 & 29 & 16 & 23 & 18 & $?$ & 13 & 11 & 13 & 23 & $?$ & 11 & 15 & 12 & $?$ \\
\hline & $\mathrm{M}$ & 14 & 13 & 29 & 16 & 24 & 17 & $11-13$ & 13 & 11 & 12 & 24 & 13 & 12 & 15 & 12 & 19 \\
\hline & $\mathrm{M}$ & 14 & 13 & 30 & 16 & 24 & 16 & $11-12.1$ & 12 & 11 & 12 & 23 & 13 & 12 & 15 & 12 & 19 \\
\hline & $\mathrm{M}$ & 14 & 14 & 31 & 16 & 25 & 17 & \begin{tabular}{|l|}
$11-15$ \\
\end{tabular} & 13 & 11 & 10 & 23 & 13 & 12 & 15 & 12 & 19 \\
\hline & $\mathrm{M}$ & 15 & 12 & 29 & 15 & 22 & 16 & 14 & 14 & 10 & 11 & 20 & 11 & 13 & 16 & 10 & 21 \\
\hline 2 & $\mathrm{M}$ & 15 & 13 & 29 & 15 & 24 & 17 & $?$ & 13 & 12 & 14 & 23 & $?$ & 14.1 & 15 & 12 & $?$ \\
\hline & $\mathrm{M}$ & 15 & 13 & 30 & 15 & 24 & 17 & $11-14$ & 13 & 11 & 12 & 23 & 13 & 12 & 15 & 12 & 19 \\
\hline 3 & $\mathrm{M}$ & 15 & 13 & 31 & 15 & 24 & 15 & $?$ & 12 & 10 & 11 & 21 & $?$ & 10 & 14 & 10 & $?$ \\
\hline & $\mathrm{M}$ & 15 & 14 & 29 & 17 & 24 & 16 & $11-15$ & 13 & 10 & 11 & 23 & 13 & 12 & 15 & 12 & 17 \\
\hline & $\mathrm{M}$ & 15 & 14 & 30 & 15 & 24 & 17 & $11-14$ & 13 & 11 & 11 & 23 & 13 & 12 & 15 & 12 & 19 \\
\hline 4 & $\mathrm{M}$ & 15 & 14 & 31 & 15 & 22 & 16 & $?$ & 13 & 10 & 12 & 22 & $?$ & 11 & 14 & 9 & $?$ \\
\hline
\end{tabular}

Table 2 - Examples of Y-STR profiles showing 4 samples with no amplification in DYS385, DYS392 and DYS448 loci (samples in yellow). 